\title{
EFFECT OF STEEL FIBERS ON FLEXURAL BEHAVIOR OF ULTRA HIGH PERFORMANCE R.C. BEAMS*
}

\author{
Hamdy K. Shehab El-Din, Mohamed M. Husain, Mahmoud A. Khater** \\ Structural Eng. Dept., Faculty of Engineering, Zagazig University, Egypt.
}

\begin{abstract}
:
Ultra-high performance fiber-reinforced concrete (UHPFRC) is a new class of concrete that has been developed in recent years. UHPFRC results from the addition of either short discrete fibers or continuous long fibers to the cement based matrix. When UHPFRC compared with high performance concrete (HPC), UHPFRC exhibits superior properties in terms of compressive behavior, tensile behavior, workability, toughness, ductility and durability. UHPFRC has exceptional mechanical and transport properties including a very high tensile strength, strain hardening, and a density leading to a very low permeability. In this research, tests were carried out on twelve ultra high performance reinforced concrete beams with $100 \mathrm{~mm} \times 200 \mathrm{~mm}$ cross section, $1600 \mathrm{~mm}$ total length to study the effects of adding steel fibers on flexural behavior of UHPC beams. The major parameters included in this research were the amount of internal steel reinforcement and the volume fraction of fibers. The test results showed that adding steel fibers to UHPC beams led to an increase in both load-carrying capacity and flexural ductility, also the concrete strain reaches to high percentage of its ultimate value that taking full advantage of the improved properties of UHPFRC, Furthermore adding steel fiber to UHPC beams can change the crack patterns, delay the crack appearance and restrain the crack expansion in concrete specimen.
\end{abstract}

KEY WORDS: UHPC, UHPFRC, Steel Fibers, R.C. Beams

\section{EFFET DE FIBRES D'ACIER SUR LE COMPORTEMENT EN FLEXION DE L'ULTRA HAUTE PERFORMANCE RC POUTRES}

\begin{abstract}
RÉSUMÉ:
Ultra-haute performance béton fibré (BFUP) est une nouvelle classe de béton qui a été développé ces dernières années. BFUP résultats de l'addition de fibres courtes soit discret ou continu des fibres longues à la matrice à base de ciment. Lorsque BFUP par rapport au béton haute performance (HPC), BFUP présente des propriétés supérieures en termes de comportement en compression, comportement à la traction, la maniabilité, la résistance, de ductilité et de longévité. BFUP a exceptionnelles propriétés mécaniques et de transport, notamment une résistance à la traction très élevée, d'écrouissage, et une densité conduisant à une très faible perméabilité. Dans cette recherche, les tests ont été effectués sur douze ultra haute performance poutres en béton armé de $100 \mathrm{~mm} \times 200 \mathrm{~mm}$ de section, $1600 \mathrm{~mm}$ de longueur totale pour étudier les effets de l'ajout de fibres d'acier sur le comportement en flexion de poutres BFUP. Les principaux paramètres inclus dans cette étude étaient la quantité d'armature en acier interne et la fraction volumique de fibres. Les résultats des tests ont montré que l'ajout de fibres d'acier à poutres BFUP ont conduit à une augmentation de la capacité de charge et la ductilité en flexion, également la souche béton atteint à fort pourcentage de sa valeur ultime en tirant pleinement parti des propriétés améliorées de BFUP, outre ajoutant fibres d'acier à poutres BFUP pouvez modifier les modèles de crack, de retarder l'apparition des fissures et limiter l'expansion fissure dans éprouvette de béton.
\end{abstract}

MOTS CLÉS: BUHP, BFUP, fibres d'acier, R.C. pouters

* Received: 25/9/2012, Accepted: 14/10/2012, Ref. No. 123, (Original Paper)

** Contact author(khater_civil@yahoo.com, +2 01226426023) 


\section{INTRODUCTION}

Ultra-high performance fibre-reinforced concrete (UHPFRC) is an advanced reinforced cementitious material. "Ultra-high performance" refers principally to improved mechanical strengths, fractural toughness, and durability. Typical behaviour of UHPFRC in a uniaxial state of stress in comparison to other concretes is shown schematically in Fig. (1). According to the French Interim Recommendations on UHPFRC [1], UHPFRC is a material with a cement matrix of a characteristic compressive strength in excess of $150 \mathrm{MPa}$, and with sufficient fiber content to achieve ductile behavior under tension. These mechanical properties enable UHPFRC to be clearly distinguished from other concretes. The Japanese recommendations [2,3] impose the same limits for strength and ductility, but also specify material composition by limiting maximal aggregate size, water-cement ratio, and fiber quantity and strength. According to the classification of fiber-reinforced concretes (FRC) proposed in [4,5], UHPFRC is distinguished between other FRCs as a material exhibiting strain hardening in tension, whereas other FRCs may exhibit a hardening behaviour in bending, but are characterised by strain softening in tension.

On the timescale of concrete development, UHPFRC can be considered as the latest innovation originally developed by Bouygues SAin 1995 [6]. The origin of advanced concretes dates back to the 1960s and 1970s with the investigations on the strength improvement of the cement paste by heat-curing under pressure $[7,8]$, or applying low water-cement ratios $[9,10]$.

Development in material science provided a better insight into the material's microstructure, and made it possible to influence the target material properties more significantly. From the 1960s onwards, more elaborated material mixtures were obtained with the introduction of fillers and superplasticizers, as described in $[11,12]$. The continually increased compactness of the matrices led to increased strength but also increased brittleness. The matrices were made more ductile by adding discontinuous fibres, an idea in evidence from the beginning of the construction era and applied to concrete since the 1960s [13].

(a)

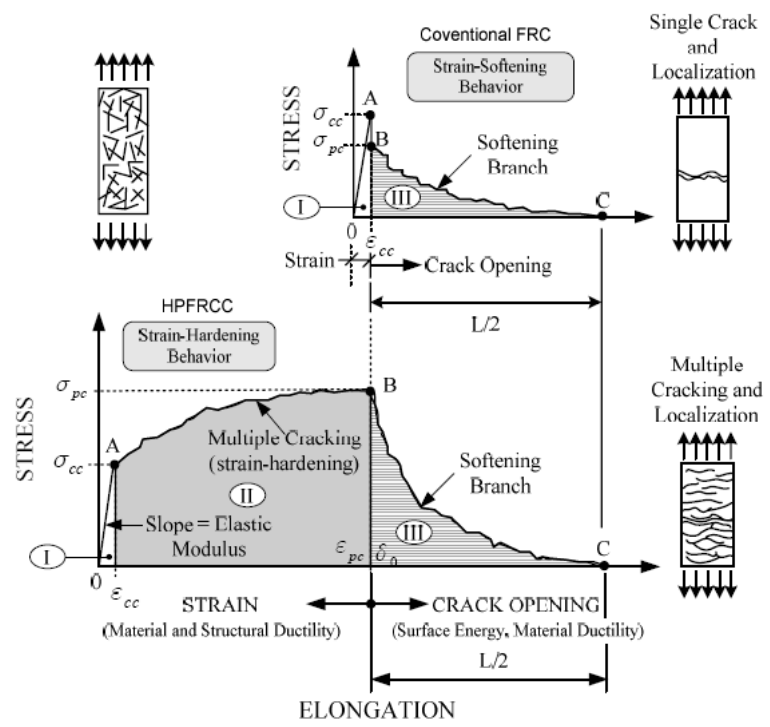

Fig. (1) Typical stress-strain or stress-elongation curve in tension up to complete separation: (a) Conventional strain-softening FRC composite, (b) Strain-hardening of HPFRCC.

In recent years the collaboration between structural and material engineering led to an integrated design, based on the tailoring of the material's composition to meet specific requirements for structural applications $[14,15,16]$. UHPFRC can be considered as the advanced result of this collaboration. The material was optimised with respect to mechanical strengths, fractural toughness, durability, placing method and time, keeping mixing and casting procedures as close as possible to existing practice $[6,17,18]$.

The objectives of this study have been:

1. What is the superior properties enhancement provided by addition of fibers with different volume fraction for UHPC beams with different amount of internal steel, and are this enhancement predictable?

2. Evaluating the failure modes of UHPC beams. 


\section{EXPERIMENTAL WORK}

\subsection{Description of tested beams}

A total of twelve UHPFRC beams with $100 \mathrm{~mm}$ $\times 200 \mathrm{~mm}$ cross section, $1600 \mathrm{~mm}$ total length, with different volume fractions of steel-fiber, 0 , 1,2 and $3 \%$ are cast and tested in this research. These UHPFRC beams were arranged into three groups as following. Details of experimental programs for all tested UHPFRC beams are given in table (1).

Table (1) Groups details and test program

\begin{tabular}{|c|c|c|c|}
\hline $\begin{array}{c}\text { Beam } \\
\text { Group }\end{array}$ & $\begin{array}{c}\text { Beam } \\
\text { Notation }\end{array}$ & $\begin{array}{c}\text { Main } \\
\text { Steel }\end{array}$ & $\begin{array}{c}\text { Volume } \\
\text { frication of } \\
\text { fiber }\end{array}$ \\
\hline \multirow{4}{*}{ Group A } & $\mathrm{A} 0$ & $2 \not 12$ & $0 \%$ \\
\cline { 2 - 4 } & $\mathrm{A} 1$ & $2 \not 12$ & $1 \%$ \\
\cline { 2 - 4 } & $\mathrm{A} 2$ & $2 \not 12$ & $2 \%$ \\
\cline { 2 - 4 } & $\mathrm{A} 3$ & $2 \not 12$ & $3 \%$ \\
\hline \multirow{5}{*}{ Group B } & $\mathrm{B} 0$ & $4 \not 12$ & $0 \%$ \\
\cline { 2 - 4 } & $\mathrm{B} 1$ & $4 \not 12$ & $1 \%$ \\
\cline { 2 - 4 } & $\mathrm{B} 2$ & $4 \not 12$ & $2 \%$ \\
\cline { 2 - 4 } & $\mathrm{B} 3$ & $4 \not 12$ & $3 \%$ \\
\hline \multirow{5}{*}{ Group C } & $\mathrm{C} 0$ & $4 \not 16$ & $0 \%$ \\
\cline { 2 - 4 } & $\mathrm{C} 1$ & $4 \not 16$ & $1 \%$ \\
\cline { 2 - 4 } & $\mathrm{C} 2$ & $4 \not 16$ & $2 \%$ \\
\cline { 2 - 4 } & $\mathrm{C} 3$ & $4 \not 16$ & $3 \%$ \\
\hline
\end{tabular}

Group (A) consist from four UHPFRC beams, had the top reinforcement of two $10 \mathrm{~mm}$ diameter bars and bottom reinforcement of two $12 \mathrm{~mm}$ diameter bars had a ratio $1.33 \%$, with transverse reinforcement of $8 \mathrm{~mm}$ diameter stirrups at $110 \mathrm{~mm}$ centers had a ratio $0.91 \%$. Group (B) consist from four UHPFRC beams, had the top reinforcement of two $10 \mathrm{~mm}$ diameter bars and bottom reinforcement of four $12 \mathrm{~mm}$ diameter bars had a ratio $2.83 \%$, with transverse reinforcement of $8 \mathrm{~mm}$ diameter stirrups at $110 \mathrm{~mm}$ centers had a ratio $0.91 \%$. Group (C) consist from four UHPFRC beams, had the top reinforcement of two $10 \mathrm{~mm}$ diameter bars and bottom reinforcement of four $16 \mathrm{~mm}$ diameter bars had a ratio $5.36 \%$, with transverse reinforcement of $8 \mathrm{~mm}$ diameter stirrups at $70 \mathrm{~mm}$ centers had a ratio $1.44 \%$. Dimensions and reinforcement of all groups are shown in Fig. (2).
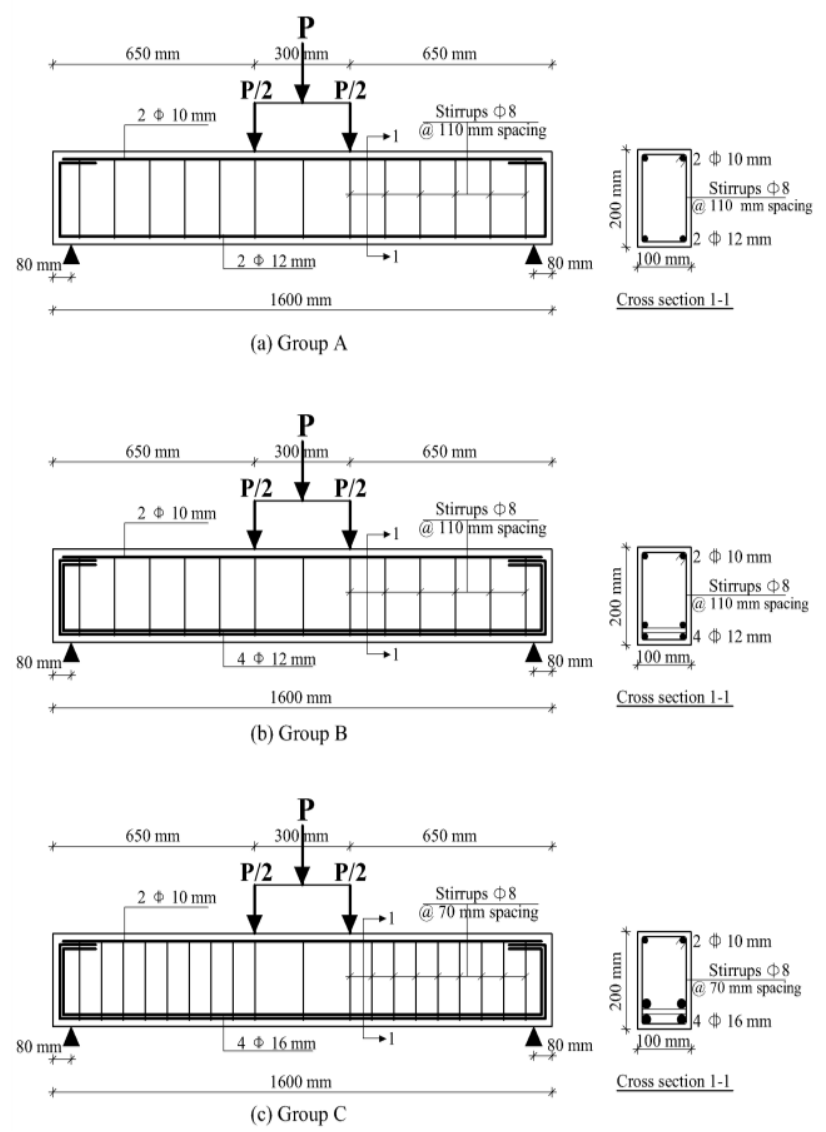

Fig. (2) Reinforcement details of tested beams

\subsection{Materials}

Natural crushed basalt graded from $2.36 \mathrm{~mm}$ to $9.5 \mathrm{~mm}$ (nominal max. size ) with fineness modulus equal 5.3 was used. Harsh desert fine sand with fineness modulus equal 2.28 was used, it was almost free from impurities, silt, loam and clay. Ordinary Portland cement with high grade $52.5 \mathrm{~N}$ was used.

The silica fume used in preparing ultra high strength concrete mixes, is locally produced by Sika Egypt (Sika Fume-HR). Sikament-NN, is used as a high-range water-reducing admixture in preparing ultra high strength concrete mixes after many trails, it complies with ASTM C494 type F and BS 5075 Part 3.

Two types of reinforcing bars were used in this work. The first was locally produced high 
strength steel with $\left(f_{\mathrm{y}} / f_{\text {ult }}=360 / 520\right)$ as deformed bars used as longitudinal reinforcement. The second one was plain normal mild steel with $\left(f_{\mathrm{y}} / f_{\mathrm{ult}}=240 / 350\right)$ was used as stirrups (web reinforcement). A steel fibers of diameter 0.60 $\mathrm{mm}$, were used in fiber concrete with length 30 $\mathrm{mm}$, with hooked end and tensile strength equal $1100 \mathrm{MPa}$, it complies with ASTM A 8 and ACI S44-3R.

\subsection{Mix Design and Sequence of UHPC}

The absolute volume method recommended by the ACI Committee was used to compute the quantities of material required for the test batch. Four mixes were designed in this work in order to get the required ultra-high compressive strength. Many trial mixes were made to adjust the proportions of the used materials to give the needed compressive strengths. The concrete mix proportions required for one cubic meter concrete are given in Table (2).

Table (2) Concrete mix proportions

\begin{tabular}{|c|c|c|c|c|}
\hline \multirow{2}{*}{ Ingredient } & \multicolumn{4}{|c|}{ Amount $\left(\mathrm{kg} / \mathrm{m}^{3}\right)$} \\
\cline { 2 - 5 } & $\begin{array}{c}\text { Batch } \\
1\end{array}$ & $\begin{array}{c}\text { Batch } \\
2\end{array}$ & $\begin{array}{c}\text { Batch } \\
3\end{array}$ & $\begin{array}{c}\text { Batch } \\
4\end{array}$ \\
\hline Cement, c & 680 & 680 & 680 & 680 \\
\hline Silica fume, s & 204 & 204 & 204 & 204 \\
\hline $\begin{array}{c}\text { Basalt } \\
\text { 2.36-5 mm }\end{array}$ & 556.6 & 545.8 & 534.9 & 524 \\
\hline $\begin{array}{c}\text { Basalt } \\
\text { 5-9.5 mm }\end{array}$ & 320 & 313.7 & 307.5 & 301.2 \\
\hline Sand & 472 & 462.8 & 453.6 & 444.3 \\
\hline \begin{tabular}{c} 
Steel fibers \\
\hline Water, w
\end{tabular} & 0 & 78 & 156 & 234 \\
\hline $\begin{array}{c}\text { Superplastici- } \\
\text { zer }\end{array}$ & 35.36 & 35.36 & 35.36 & 35.36 \\
\hline w/c & 0.22 & 0.22 & 0.22 & 0.22 \\
\hline w/(c+s) & 0.17 & 0.17 & 0.17 & 0.17 \\
\hline
\end{tabular}

It is important to have a homogeneous concrete mix, therefore, cement, silica fume, coarse and fine aggregate were premixed for about 2-3 min. Then, water and water-reducing admixture were added and mixed for about $1 \mathrm{~min}$. When the mixture became flowable, the steel fibers were added and mixed for an additional $1 \mathrm{~min}$. All mixing procedures were carried out at room temperature about $\left(20-25^{\circ}\right)$.

\subsection{Strength Properties of UHPC}

The compression test was carried - out on cube specimens $(100 \times 100 \times 100 \mathrm{~mm})$ after 28 days curing, the strength increase as the fiber content becomes higher. The tensile splitting test was carried - out on cylinder specimens $(100 \times 200$ $\mathrm{mm}$ ) after 28 days curing, the tensile splitting strength increase as the fiber content becomes higher as shown in Table (3). The consistency of the concrete was measured by slump test apparatus.

The uniaxial compressive test was carried - out on cylinder specimens (100 x $200 \mathrm{~mm})$ after 28 days curing, with invariable loading rate of $0.15 \mathrm{MPa} / \mathrm{s}$ [19]. In this test, electrical strain gauge was located on the face of cylinder specimens in order to measure vertical strain under compressive test. Strain for each 0.50 $\mathrm{MPa}$ stress were recorded and were used to calculate the modulus of elasticity. The values of modulus of elasticity shown in Table (3).

Table (3) Tests carried out on control specimens

\begin{tabular}{|c|c|c|c|c|}
\hline Test & $\begin{array}{c}\text { Batch } \\
1\end{array}$ & $\begin{array}{c}\text { Batch } \\
2\end{array}$ & $\begin{array}{c}\text { Batch } \\
3\end{array}$ & $\begin{array}{c}\text { Batch } \\
4\end{array}$ \\
\hline $\begin{array}{c}\text { Cube compressive } \\
\text { strength(MPa) }\end{array}$ & 169 & 174 & 177 & 180 \\
\hline $\begin{array}{c}\text { Tensile splitting } \\
\text { strength (MPa) }\end{array}$ & 9.5 & 11.1 & 12.7 & 13.1 \\
\hline $\begin{array}{c}\text { Modulus of } \\
\text { elasticity (GPa) }\end{array}$ & 46.2 & 48.3 & 49.1 & 49.6 \\
\hline Slump (mm) & 120 & 90 & 70 & 50 \\
\hline
\end{tabular}

\subsection{Test Procedure}

Deflections were measured at mid span of the beams and under the concentrated loads. Two Linear Variable Distance Transducers ,LVDT, having a maximum range of $100 \mathrm{~mm}$ and reading to $0.01 \mathrm{~mm}$ were used in the test. Strains were determined at different positions of the beams as shown in Fig. (3). Electrical strain gages produced by KYOWA ELECTRONIC INSTRUMENTS CO., LTD., Tokyo, Japan. The product type for the steel and the concrete were KFG-5-120-C1-11 and KFG-50-120-C1-11 respectively. The strain gages data were collected using a data logger system.

The available hydraulic testing machine (Avery Denison-England, 1000 KN PU) was used, 
which controlled the concrete dimensions of the tested beams. The beams were rested on two hinged supports to avoid restraint to the elongation of the bottom of fibers of the beams as load was applied. The applied load by the testing machine was transmitted to the tested beams through a spreader beam (I-beam) supported on two cylinder bars giving two point loading test in order to obtain a zone of constant bending moment and zero shear. The distance between the two loading points was taken 300 mm for beams with span $1440 \mathrm{~mm}$. Fig. (3) shows the loading arrangement and the overall test setup.

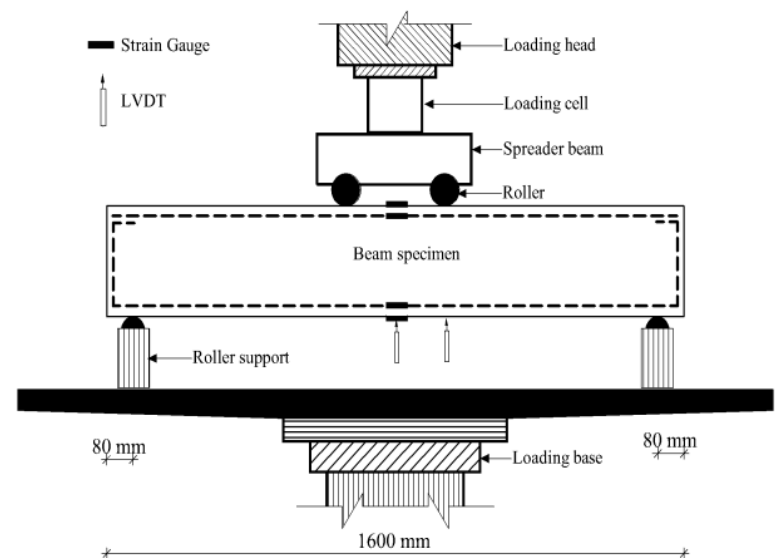

Fig. (3) Test setup showing loading arrangement and measuring instruments

\section{EXPERIMENTAL RESULTS AND DISCUSSION}

\subsection{Failure Mode}

Modes of failure of the tested beams are shown in Table (4). The modes of failure observed for the tested beams can be divided into two categories. The first was ductile flexural failure (tension failure) observed in all beams of group (A) and group (B). The second was brittle compression failure (concrete crushing) with shear cracks and it was observed in beams $\mathrm{C} 0$ and $\mathrm{C} 1$ in group (C).

All tested beams exhibited three stage responses up to failure; representing the concrete precracking stage, concrete postcracking to tension steel preyield stage and tension steel postyield stage to failure. In the uncracked elastic stage, cracks were not observed when the load was increased linearly at the beginning of the test. The first micro-cracks occurred at the bottom face of the beam between the loading points where the beam was subjected to pure bending. The initiation of cracks appeared in the form of several micro-cracks with a sparse distribution. As the test progressed after first cracking, new micro-cracks started to develop between the existing cracks. Most of the cracks continued to propagate toward the upper face, and the cracks did not visually widen. This pattern is different from the typical propagation pattern of flexural cracks in UHPC beams without fibers shown in Figs. (4), (6), (8).

Tensile failure of UHPC generally occurs when the steel fiber begins to pull out of the UHPC matrix. Mechanically, pullout occurs when the load carried by an individual fiber overcomes the ability of the UHPC to grip the fiber. Fibers that are pulled out increase the load that other fibers nearby must carry. As the load on the beam increased, more cracks formed and the fibers bridging the existing cracks experienced more stress. At the peak load carried by the beam, the fibers at one specific cross section began to pull out This crack width became significantly wider than any other crack in the beam. Eventually, the fibers bridging the highly stressed crack began to pull out. Thereafter, the failure of the beam was precipitated by the local bond failure between fibers and the UHPC matrix as well as rebar yielding. These test results indicate that fiber pullout resulted in member failure and that the failure occurred via flexural failure.

By increasing the volume fraction of fiber to $2 \%$ for group (A) and 3\% for group (B) and group (C), the failure occurs in the tensile zone following the appearance of one macro crack at midspan in the central zone of constant moment, as shown in Figs. (5), (7), (9). This macro crack occurs when the lower level of reinforcement fails. In this case, the concrete strain reaches to high percentage of its ultimate value that reach a significant level of ductility taking full advantage of the improved properties of UHPC. 
EFFECT OF STEEL FIBERS ON FLEXURAL BEHAVIOR OF ULTRA HIGH PERFORMANCE R.C. BEAMS

Shehab El-Din, Husain, Khater

Table (4) Test results and observed failure modes

\begin{tabular}{|c|c|c|c|c|c|c|c|c|}
\hline \multirow{2}{*}{ 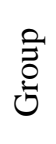 } & \multirow{2}{*}{$\begin{array}{l}\stackrel{0}{\stackrel{0}{0}} \\
z\end{array}$} & \multicolumn{2}{|c|}{ Yield } & \multicolumn{2}{|c|}{ Ultimate } & \multicolumn{2}{|c|}{ Strains at ultimate $\times 10^{-3}$} & \multirow[b]{2}{*}{ Failure mode } \\
\hline & & $\begin{array}{c}\text { Load } \\
(\mathrm{kN})\end{array}$ & $\begin{array}{l}\text { Deflection } \\
\quad(\mathrm{mm})\end{array}$ & $\begin{array}{l}\text { Load } \\
(\mathrm{kN})\end{array}$ & $\begin{array}{l}\text { Deflection } \\
\quad(\mathrm{mm})\end{array}$ & Concrete & Steel & \\
\hline \multirow{4}{*}{ A } & A0 & 59 & 12.9 & 70 & 25.5 & 2.1 & 32.4 & Flexural tension failure \\
\hline & $\mathrm{A} 1$ & 61 & 13.2 & 75 & 27.3 & 2.8 & 35.6 & Flexural tension failure \\
\hline & A2 & 64 & 13.4 & 83 & 30.2 & 3.5 & 38.3 & Flexural tension failure \\
\hline & $\mathrm{A} 3$ & 70 & 13.7 & 93 & 34.1 & 4.3 & 42.2 & Flexural tension failure \\
\hline \multirow{4}{*}{ B } & B0 & 126 & 11.5 & 143 & 18.1 & 2.6 & 19.1 & Flexural tension failure \\
\hline & B1 & 130 & 11.4 & 152 & 22.5 & 3.5 & 21.3 & Flexural tension failure \\
\hline & B2 & 137 & 11.7 & 161 & 25.4 & 4.4 & 24.5 & Flexural tension failure \\
\hline & B3 & 143 & 11.9 & 173 & 27.3 & 5.4 & 26.7 & Flexural tension failure \\
\hline \multirow{4}{*}{$\mathrm{C}$} & $\mathrm{C} 0$ & 221 & 9 & 246 & 11.2 & 3 & 8.4 & Concrete crushing \\
\hline & $\mathrm{C} 1$ & 223 & 8.7 & 250 & 13.1 & 3.5 & 10.1 & Concrete crushing \\
\hline & $\mathrm{C} 2$ & 225 & 8.6 & 256 & 15.2 & 4.6 & 11.5 & Flexural tension failure \\
\hline & $\mathrm{C} 3$ & 228 & 8.6 & 266 & 17.8 & 5.6 & 12.6 & Flexural tension failure \\
\hline
\end{tabular}

At the same load level of cracking stage, the crack of UHPC beams without steel fibers is far longer than UHPC beams with steel fibers. In addition, a larger amount of steel fiber is required when the tension steel ratio increased in order to reach a significant level of ductility.

As the tension steel ratio increased, diagonal tension crack occurred in wider area. In addition, high percentage of internal steel had a ratio $5.36 \%$ change the failure mode from ductile flexural failure to brittle compression failure with shear cracks for beams $\mathrm{C} 0$ without steel fiber as shown in Fig. (8).

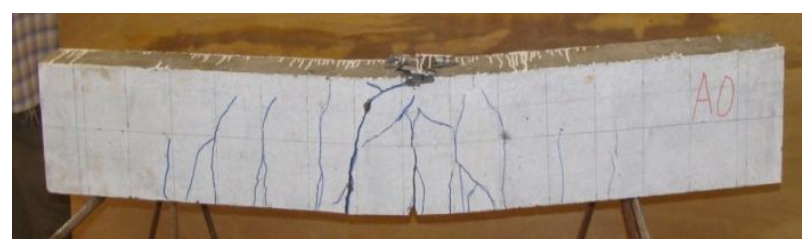

Fig. (4) Mode of failure of tested beam AO

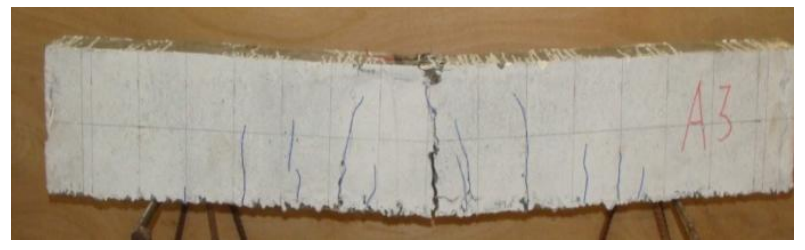

Fig. (5) Mode of failure of tested beam A3

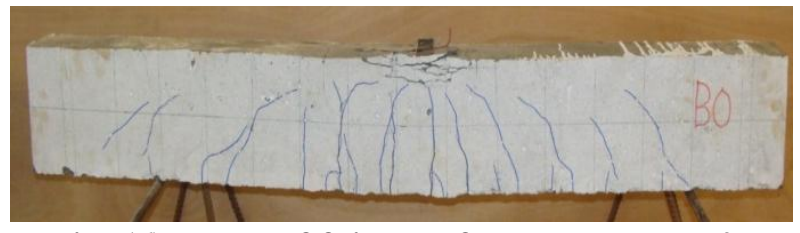

Fig. (6) Mode of failure of tested beam B0

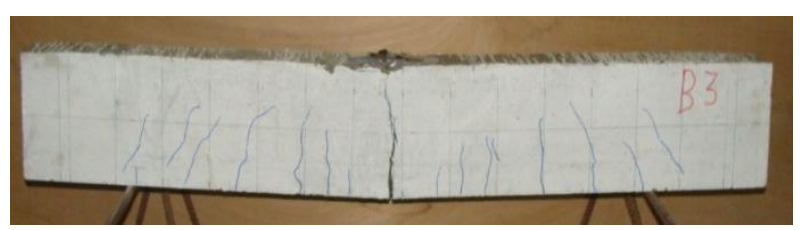

Fig. (7) Mode of failure of tested beam B3

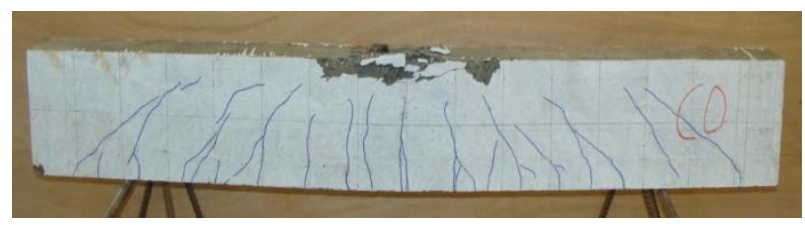

Fig. (8) Mode of failure of tested beam C0

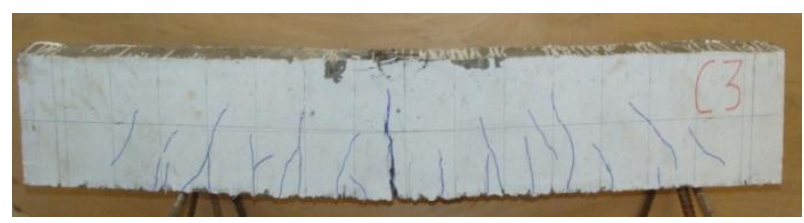

Fig. (9) Mode of failure of tested beam C3 


\subsection{Load - Deflection Relationship}

Deflection of the tested beams was measured at mid-span for each beam. Table (4) showed the max. values of deflections for each beam at different stage of loading. Figs. (10), (11), (12) were plotted to represent the relation between load and the corresponding central deflection, the main variables considered in these figures are the amount of internal steel reinforcement and the volume fraction of the fiber. It can be seen that all the beams exhibited linear behavior from initial loading up to the occurrence of the first crack. After the formation of the cracks, all beams showed non-linear behavior. Comparison of the peak deflection at ultimate load reveals that there was great improvement in the ductility, due to the inclusion of steel fiber. Test results showed that the vertical deflection is directly proportional to amount of steel fibers. Test results have also showed that the lower the amount of ordinary internal steel bars the lower the flexural ductility enhancement achieved by adding fibers to UHPC beams.

Figs. (10), (11), (12) indicated that the increase of volume fraction of fiber from $0 \%$ to $3 \%$ for UHPC beams causes increase in ultimate loads by $32.86 \%$ for beams with internal steel ratio $1.33 \%$, by $20.98 \%$ for beams with internal steel ratio $2.83 \%$ and by $8.13 \%$ for beams with internal steel ratio $5.36 \%$. Hence, the increase in terms of ultimate load provided by steel fiber reinforcement was as significant as lower the percentage of the conventional internal steel ratio.

Figs. (10), (11), (12) also indicated that the increase of volume fraction of fiber from $0 \%$ to $3 \%$ for UHPC beams causes increase in deflection levels by $33.7 \%$ for beams with internal steel ratio $1.33 \%$, by $51.1 \%$ for beams with internal steel ratio $2.83 \%$ and by $59.3 \%$ for beams with internal steel ratio $5.36 \%$. Hence, the increase in terms of deflection levels provided by steel fiber reinforcement was as significant as higher the percentage of the conventional internal steel ratio.

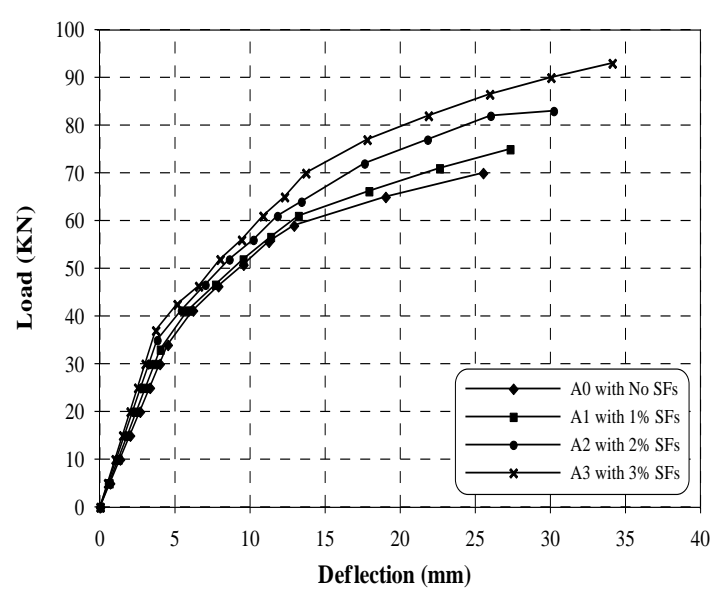

Fig. (10) Load - Deflection curve of UHPC beams of group (A) with internal steel ratio $(\rho)=1.33 \%$

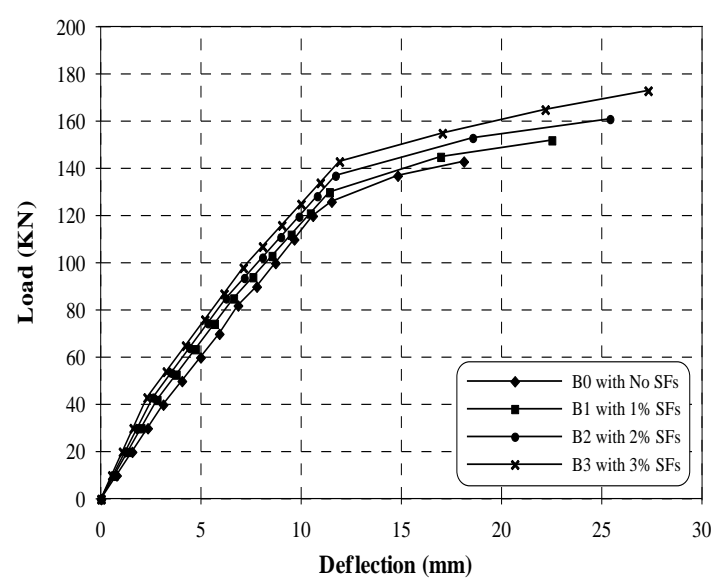

Fig. (11) Load - Deflection curve of UHPC beams of group (B) with internal steel ratio $(\rho)=\mathbf{2 . 8 3} \%$

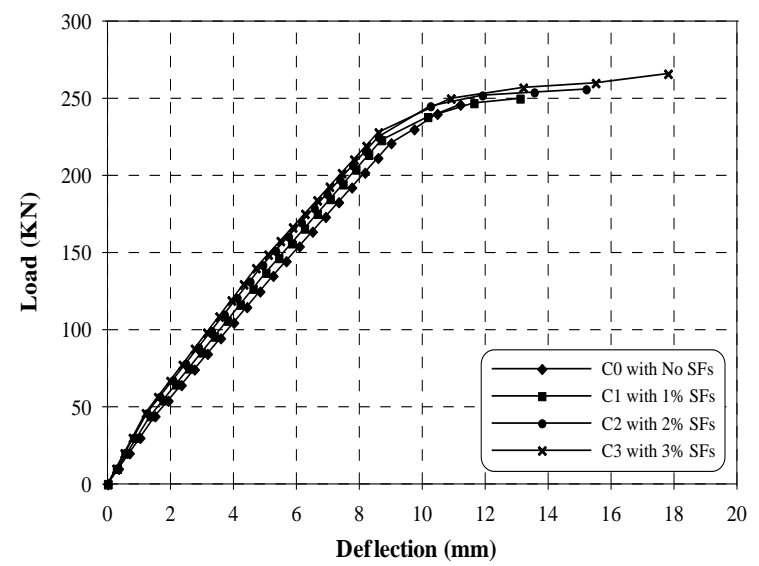

Fig. (12) Load - Deflection curve of UHPC beams of group $(C)$ with internal steel ratio $(\rho)=5.36 \%$ 


\subsection{Load - Strain Relationship}

Strains of the tested beams were measured at mid-span for each beam. Table (4) shows the maximum values of strains for concrete in compression, steel in tension. Figs. from (13) to (18) were plotted to represent the relation between load and the corresponding central strain, the main variables considered in these figures are the amount of internal steel reinforcement and the volume fraction of the fiber. Comparison of the strains at ultimate load reveals that there was great improvement in the strain levels, due to the inclusion of steel fiber.

Figs. from (13) to (15) were drawn to show the effect of steel fibers on the load - midspan compressive concrete strain of UHPC beams. Test results showed that the compressive concrete strain is directly proportional to amount of steel fibers. Also the results showed that for UHPC beams, once reaching the ultimate, concrete failed by crushing and strain in the reinforcement dropped suddenly. However in UHPFRC beams, when beams reached the ultimate, concrete was held together and the strain in concrete and strain in reinforcement kept increasing gradually. It was also observed that, in the UHPC beams with fibers, the stress in steel bars increases until the steel reaches its yield point. Thereafter, a large portion of any extra stress is absorbed by large deformations in the steel, which lowers the increase of concrete compressive strain.

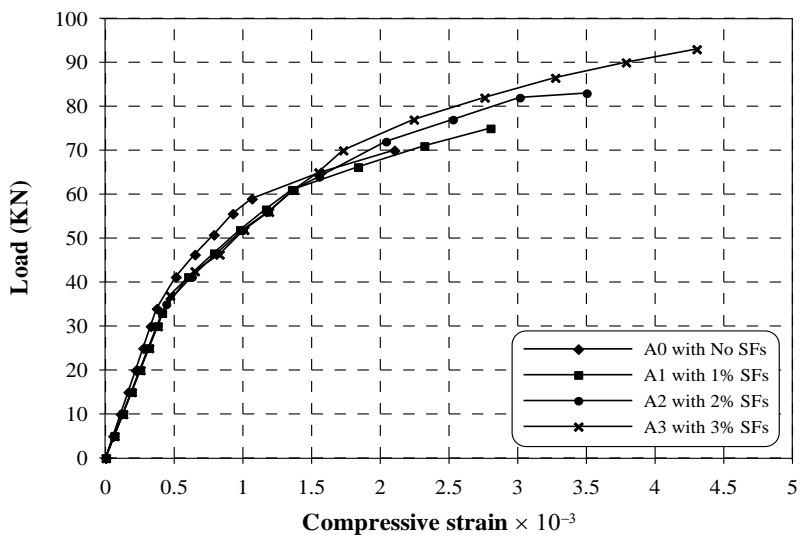

Fig. (13) Load - Maximum compressive strain curve of UHPC beams of group (A) with internal steel ratio $(\rho)=1.33 \%$

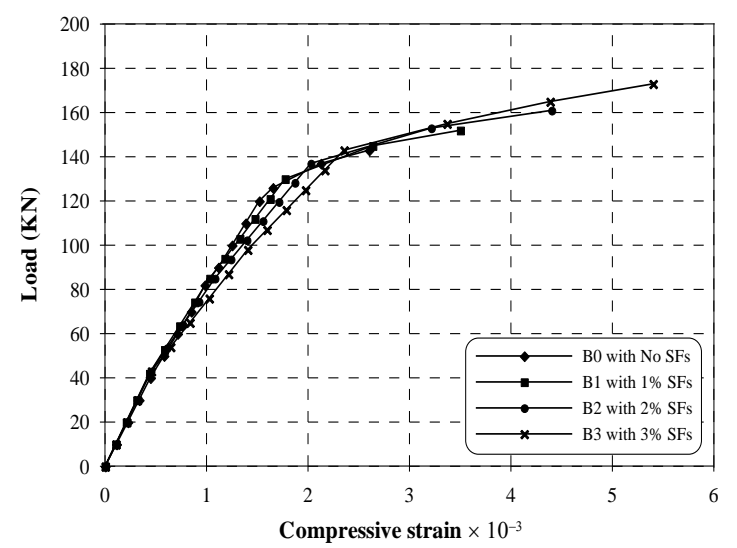

Fig. (14) Load - Maximum compressive strain curve of UHPC beams of group (B) with internal steel ratio $(\rho)=\mathbf{2 . 8 3} \%$

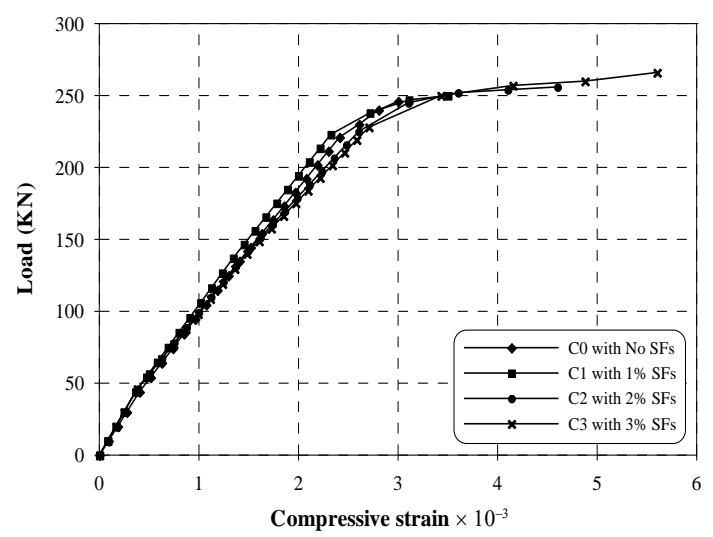

Fig. (15) Load - Maximum compressive strain curve of UHPC beams of group (C) with internal steel ratio $(\rho)=5.36 \%$

Figs. from (16) to (18) showed the effect of steel fibers on the load - midspan tensile steel strain of UHPC beams. Test results showed that the tensile steel strain is directly proportional to amount of steel fibers.

By decreasing the steel reinforcement ratio, one can obtain a ductile failure by steel yielding, but with a low compression level in the concrete (about $60 \%$ of the ultimate strain of the concrete in compression). This does not take full advantage of the improved properties of UHPC. The design goal is the achievement of "ductile" structures that reach a significant level of strain in the compression zone at failure. For this purpose, it is necessary to use a material with higher tensile properties with steel. 


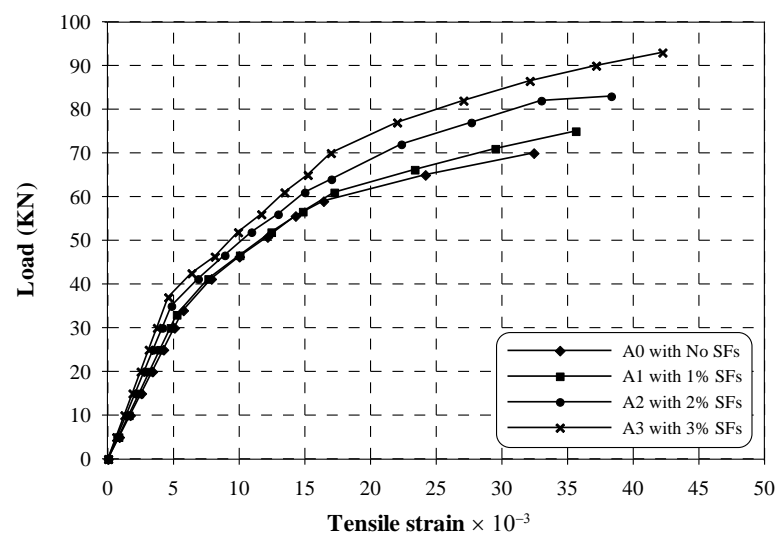

Fig. (16) Load - Maximum tensile strain curve of UHPC beams of group (A) with internal steel ratio $(\rho)=1.33 \%$

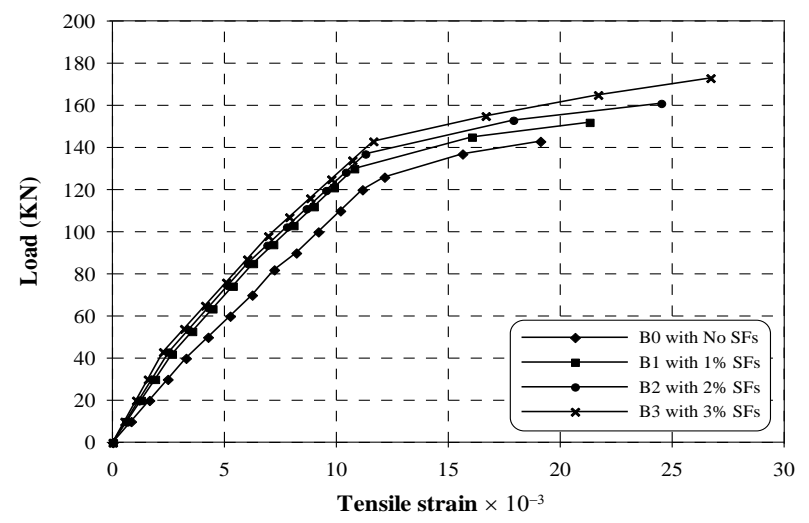

Fig. (17) Load - Maximum tensile strain curve of UHPC beams of group (B) with internal steel ratio $(\rho)=2.83 \%$

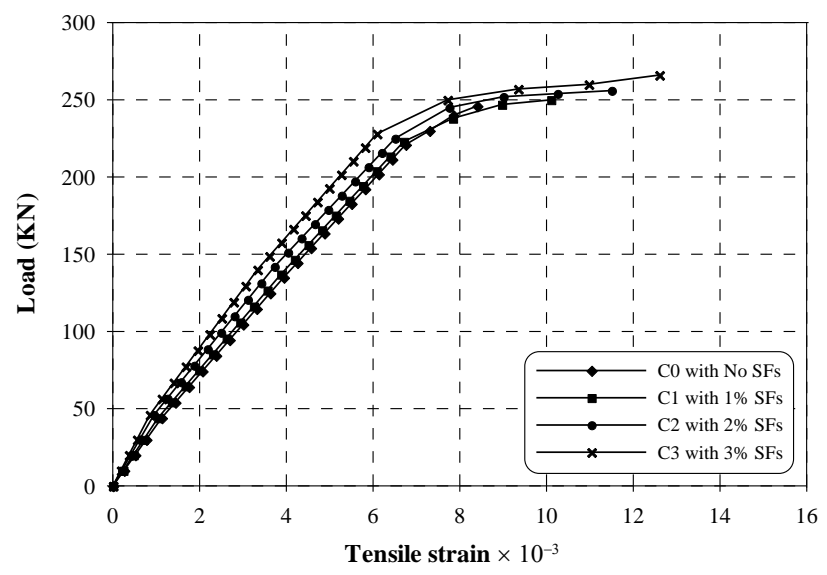

Fig. (18) Load - Maximum tensile strain curve of UHPC beams of group (C) with internal steel ratio $(\rho)=5.36 \%$

\section{CONCLUSIONS}

Findings from the experimental study on the effect of adding steel fibers on flexural behavior of UHPC beams are as follows:

1. By increasing the volume fraction of fiber to $2 \%$ for UHPC beams with internal steel ratio $1.33 \%$ and to $3 \%$ for UHPC beams with internal steel ratio $2.83 \%$ and $5.36 \%$, the failure occurs in the tensile zone following the appearance of one macro crack at midspan in the central zone of constant moment. This macro crack occurs when the lower level of reinforcement fails. In this case, the concrete strain reaches high percentage of its ultimate value, taking full advantage of the improved properties of UHPC.

2. Adding fibers to UHPC beams can change the crack patterns, delay the crack appearance and restrain the crack expansion in concrete specimen.

3. The cracking and failure patterns of UHPC beams reveal that many tightly spaced cracks formed perpendicular to flexural tensile forces in the UHPC beam. These results indicate the ability of UHPC to redistribute stresses and undergo multiple cracks before fiber pullout.

4. The concrete ultimate strains measured in UHPC beams with steel fiber were larger than that of the UHPC beams without steel fiber. They ranged from 4.3 microstrains to 6.9 microstrains with an average of 5.5 microstrains for UHPC beams with steel fiber. While 2.1 microstrains to 3.0 microstrains with an average of 2.6 microstrains were measured for UHPC beams without steel fiber.

5. The increase of ultimate load provided by steel fiber reinforcement for UHPC beams was higher for lower value of conventional internal steel ratio $(\rho)$. The increase of volume fraction of steel fiber from $0 \%$ to $3 \%$ for UHPC beams causes maximum increase in ultimate loads by $32.86 \%$ for $\rho=1.33 \%$, by $20.98 \%$ for $\rho=2.83 \%$ and by $8.13 \%$ for $\rho$ $=5.36 \%$. 
6. The increase of deflection levels provided by steel fiber reinforcement for UHPC beams was higher for higher value of conventional internal steel ratio $(\rho)$. The increase of volume fraction of steel fiber from $0 \%$ to $3 \%$ for UHPC beams causes maximum increase in deflection level by $33.7 \%$ for $\rho=1.33 \%$, by $51.1 \%$ for $\rho=2.83 \%$ and by $59.3 \%$ for $\rho$ $=5.36 \%$.

7. The UHPC beams of higher steel-fiber fraction had better deformational behavior. Also, at the same load level the crack propagation was effectively controlled.

\section{REFRENCES}

[1] SETRA, AFGC, "Béton fibrés à ultrahautes performances, (Ultra high performance fibre reinforced concretes)," recommandations provisoires, 152 p., France, Janvier, 2002.

[2] JSCE, "Recommendations for Design of UHSFRC Structures, " Japan Society of Civil Engineers, 2004.

[3] JSCE , "Recommendations for Design and Construction of Ultra High Strength Concrete Structures, Draft, ” Japan Society of Civil Engineers, September, 2006.

[4] Naaman A. E. and Reinhardt H. W. , “ Proposed classification of HPFRC composites based on their tensile response, " Materials and Structures, 39, pp. 547555, 2006.

[5] Stang H. and Li V. C. , " Classification of Fibre Reinforced Cementitious Materials for Structural Applications, " 6th RILEM Symposium on fibre reinforced concrete (FRC), - BEFIB 2004, Varenna, Italy, pp. 197-218, September, 2004.

[6] Richard P. and Cheyrezy M. , “ Composition of Reactive Powder Concretes, " Cement and Concrete Research, vol. 25, no. 7, pp 1501-1511, USA, October, 1995.
[7] Roy D. M. and Gouda G. R., "High strength generation in cement pastes," Cement and Concrete Research, Vol. 3, pp 807-820, 1973.

[8] Roy D. M., Gouda G. R. and Bobrowsky A. , "Very high strength cement pastes prepared by hot pressing and other high pressure techniques, " Cement and Concrete Research, Vol. 2, pp 349-366, USA, 1972.

[9] Yudenfreund M., Odler I. and Brunauer S. , "Hardened Portland Cement Pastes of Low Porosity, I. Materials and Experimental Methods, "Cement and Concrete Research, Vol. 2, No. 3, pp 313330, USA, May, 1972.

[10] Yudenfreund M., Hanna K. M., Skalny J., Odler I. and Brunauer S. , "Hardened Portland Cement Pastes of Low Porosity, V. Compressive Strength, "Cement and Concrete Research, Vol. 2, pp 731-743, USA, 1972.

[11] Mielenz R. C. , “ History of chemical admixtures for concrete, " Concrete International, Vol. 6, Issue 4, p. 40-54. , April, 1984.

[12] ACI , "Superplasticizers and Other Chemical Admixtures in Concrete, " SP119, 665 pp., 1989.

[13] Romualdi J. P. and Mandel J.A., "Tensile strength of concrete affected by uniformly distributed and closely spaced short lengths of wire reinforcement, "Journal of the American Concrete Institute, 61, No. 6, pp. 657-671, June, 1964.

[14] Van Mier J. G. M. , “Fracture Processes of Concrete - Assessment of Material Parameters for Fracture Models, " 448 p., Boca Raton, USA, 1997.

[15] Van Mier J. G. M., "Strain-softening of concrete in uniaxial compression - Report of the round robin test carried out by RILEM TC 148-SSC, " Materials and 
Structures, Vol. 30, pp. 195-209, May, 1997.

[16] Li V. C. and Fischer G. , "Reinforced ECC - An Evolution from Materials to Structures, " Proceedings of the 1st fib congress - Concrete Structures in the $21 \mathrm{st}$ Century, pp. 105 -122, Osaka, 2002.

[17] Acker P. and Behloul M., "Ductal Technology: a Large Spectrum of Properties, a Wide Range of Applications," Proceedings of the International Symposium on Ultra High Performance Concrete, Kassel, pp. 11-23, 2004.

[18] Acker P., "Swelling, shrinkage and creep: a mechanical approach to cement hydration," Materials and Structures, Vol. 37, pp. 237-243, May, 2004.

[19] H. Akbarzadeh and A.A. Maghsoudi, "Experimental and analytical investigation of reinforced high strength concrete continuous beams strengthened with fiber reinforced polymer," Materials and Design 31 (2010) 1130-1147. 